\author{
AGNIESZKA MALICKA \\ ORCID: 0000-0003-1722-7300 \\ Uniwersytet Wrocławski \\ Szkoła Prawa Niemieckiego \\ Pracownia Nauczania Prawa w Językach Obcych
}

\title{
UDZIAŁ OBYWATELI W PROCEDURZE USTAWODAWCZEJ W REPUBLICE FEDERALNEJ NIEMIEC
}

\begin{abstract}
Abstrakt: Według art. 20 Ustawy Zasadniczej Republika Federalna Niemiec jest państwem demokratycznym, socjalnym i federalnym, w którym cała władza pochodzi od narodu i jest przez niego sprawowana poprzez wybory i głosowania. W praktyce głosowania, rozumiane jako instrument demokracji bezpośredniej, znajdują zastosowanie tylko w wypadku nowego podziału terytorialnego landów. Szersze zastosowanie instrumenty demokracji bezpośredniej mają przy stanowieniu prawa w poszczególnych landach. Prawo przewiduje w nich między innymi obywatelską inicjatywę ustawodawczą. Dla uchwalenia prawa federalnego zastosowanie takiego rozwiązania wymagałoby zmiany Ustawy Zasadniczej. Wnoszone do tej pory projekty takich zmian zostały jednak odrzucone przez Bundestag.
\end{abstract}

Słowa kluczowe: postępowanie ustawodawcze, Bundestag, demokracja bezpośrednia, demokracja reprezentacyjna, inicjatywa ustawodawcza, referendum

\section{KILKA WSTĘPNYCH UWAG O DEMOKRACJI BEZPOŚREDNIEJ W NIEMCZECH}

Zgodnie $\mathrm{z}$ jedną $\mathrm{z}$ podstawowych zasad ustrojowych zawartych $\mathrm{w}$ art. 20 Ustawy Zasadniczej ${ }^{1}$ Republika Federalna Niemiec jest demokratycznym i socjalnym państwem federalnym, cała zaś władza państwowa pochodzi od narodu i jest sprawowana przezeń na drodze wyborów i głosowań. Oznacza to, że w Niemczech, podobnie jak w wielu innych państwach demokratycznych, zasada suwerenności na-

${ }^{1}$ Das Grundgesetz für die Bundesrepublik Deutschland vom 23. Mai 1949 (BGBl S. 1), https:// www.gesetze-im-internet.de/gg/index.html (dostęp: 2.02.2020). W dalszej części publikacji autorka przy powoływaniu przepisów niemieckiej ustawy zasadniczej posługuje się skrótem UZ. 
rodu realizowana jest przede wszystkim w ramach demokracji przedstawicielskiej ${ }^{2}$, a instrumenty demokracji bezpośredniej mają jedynie charakter uzupełniający33.

Demokracja bezpośrednia nie ma w Niemczech zbyt długiej tradycji. Po raz pierwszy jej elementy zostały włączone do systemu prawa w 1918 roku na podstawie Konstytucji Weimarskiej ${ }^{4}$. Obecnie możliwość stosowania instrumentów demokracji bezpośredniej na poziomie federalnym należy traktować jako rozwiązanie wyjątkowe. Zgodnie z art. $29 \mathrm{UZ}$ referendum może zostać przeprowadzone w wypadku dokonania zmian $\mathrm{w}$ dotychczasowym podziale terytorialnym Niemiec ${ }^{5}$ oraz przyjęcia nowej konstytucji, co przewiduje art. 146 UZ. Bezpośredni udział obywateli w federalnym procesie ustawodawczym lub w decyzjach o ważnych dla całej Federacji sprawach nie jest w świetle obecnie obowiązujących przepisów Ustawy Zasadniczej możliwy.

Od lat w Niemczech trwają dyskusje nad wprowadzeniem odpowiednich zmian w prawie, umożliwiających stosowanie instrumentów demokracji bezpośredniej także na poziomie całej Federacji. Do Bundestagu wpłynęły wprawdzie projekty ustaw, jednak do tej pory odpowiednie przepisy nie zostały przyjęte ${ }^{6}$. Kryzys demokracji, który w ostatnich latach ma miejsce w wielu państwach, i nieoczekiwane skutki decyzji podejmowanych na drodze referendów, na przykład Brexit, powodują, że proponowane zmiany Ustawy Zasadniczej, umożliwiające obywatelom współdecydowanie o ważnych dla państwa sprawach mają tyle samo zwolenników co przeciwników ${ }^{7}$. Przeciwnicy dodatkowo powołują się na dotychczasowe negatywne historyczne wydarzenia związane z demokracją bezpośrednią okresu Republiki Weimarskiej i III Rzeszy ${ }^{8}$.

${ }^{2}$ Zob. m.in. J. Isensee, Demokratie ohne Volksabstimmung, [w:] 60 Jahre Bonner Grundgesetz - eine geglückte Verfassung?, red. Ch. Hillgruber, Ch. Waldhoff, Bonn 2010, s. 120.

3 Świadczy o tym między innymi umieszczenie głosowań jako formy sprawowania władzy przez suwerena na ostatnim miejscu, po wyborach. Zob. I. von Münch, Staatsrecht, t. 1, wyd. 6, Stuttgart-Berlin-Köln 2000, s. 54; oraz Grundgesetz. Mitarbeiterkommentar und Handbuch, t. 1, red. D. Umbach, T. Clemens, Heidelberg 2002, s. 1303.

${ }^{4}$ Konstytucja Rzeszy Niemieckiej — Die Verfassung des Deutschen Reichs/Weimarer Rechsverfassung, http://www.documentarchiv.de/wr/wrv.html (dostęp: 7.02.2020).

${ }^{5}$ Referendum dotyczące zmiany dotychczasowych granic krajów związkowych w rzeczywistości nie jest referendum ogólnokrajowym, ponieważ do udziału w nim uprawnieni są jedynie posiadający prawo wyborcze obywatele landów, których dotyczą zmiany terytorialne.

${ }^{6}$ Projekt wniesiony do Bundestagu 19. kadencji przez partię Die Linke po wyborach parlamentarnych 24 października 2017 roku (Drucksache 19/16) przepadł w głosowaniu. Treść projektu oraz informacje o pracach parlamentarnych zob. https://www.bundestag.de/dokumente/textarchiv/2018/ kw24-de-direkte-demokratie-558872 (dostęp: 5.02.2020). Na rozpatrzenie czeka projekt wniesiony do Bundestagu w sierpniu 2019 roku przez kontrowersyjną partię AfD; zob. Entwurf eines Gesetzes zur Stärkung der direkten Demokratie im Grundgesetz (Drucksache 19/12371), https://www.bundestag.de/services/suche?suchbegriff=drucksache+19\%2F12371 (dostęp: 5.02.2020).

${ }^{7}$ Zob. Lexikon Direkte Demokratie in Deutschland, red. A. Kost, M. Solar, Wiesbaden 2018 , s. $1-2$.

${ }^{8}$ Przy pracach nad Ustawą Zasadniczą Rada Parlamentarna uwzględniła negatywne doświadczenia w korzystaniu z instrumentów demokracji bezpośredniej w Republice Weimarskiej i III Rzeszy, a także zrezygnowała z nich w UZ.

Przegląd Prawa i Administracji CXX, 2020, cz. 1 i 2

(C) for this edition by CNS 


\section{PROCES USTAWODAWCZY W NIEMCZECH}

Z zasady federalizmu i podziału kompetencji między Federację a kraje związkowe/landy wynika między innymi podział na prawo federalne (Bundesrecht) i prawo krajów związkowych/landów (Landesrecht). Obok obowiązującej dla całej Federacji Ustawy Zasadniczej każdy z landów ma swoją konstytucję (Verfassung) Landesverfassung); z Ustawy Zasadniczej wynikają jednak zasady obowiązywania prawa federalnego i prawa poszczególnych landów oraz podział kompetencji ustawodawczych pomiędzy Bundestag oraz parlamenty landów (Landtage) ${ }^{9}$. Prawo federalne stanowione przez Bundestag i Bundesrat obowiązuje na terytorium całych Niemiec, natomiast w każdym z 16 landów Landtagi stanowią prawo krajowe, obowiązujące tylko w konkretnym landzie. Zgodnie z zasadą hierarchicznego systemu norm prawnych prawo landów nie może kolidować z prawem federalnym zarówno pod względem formalnym, jak i merytorycznym. $Z$ art. $31 \mathrm{UZ}$ bezpośrednio wynika zasada prymatu prawa federalnego — ma ono zawsze pierwszeństwo przed prawem landu, także przed jego konstytucją. Nad przestrzeganiem zasady prymatu prawa federalnego przed krajowym czuwa Federalny Trybunał Konstytucyjny ${ }^{10}$.

\section{USTAWODAWSTWO FEDERALNE}

Federalny proces ustawodawczy uregulowany jest bezpośrednio w Ustawie Zasadniczej, a szczegółowe przepisy zawierają regulaminy Bundestagu ${ }^{11}$ i Bundesratu ${ }^{12}$ oraz Komisji Wspólnej ${ }^{13}$ tych izb. W niemieckim systemie prawa rozróżnia się dwie kategorie ustaw: ustawy zwykłe (Einspruchsgesetze), wobec których w ramach postępowania ustawodawczego Bundesrat może wnieść swój sprzeciw, oraz ustawy zawsze wymagające do ich uchwalenia i wejścia w życie zgody Bundesratu (zustimmungspflichtige Gesetze). W wypadku ustaw powodujących znacz-

${ }^{9}$ Kompetencja ustawodawcza landów wynika z art. 70 UZ. Podział kompetencji ustawodawczych regulują art. 71-74 UZ. Niemiecki system prawa wyróżnia zakres wyłącznego ustawodawstwa federalnego — art. $71 \mathrm{UZ}$, tak zwane ustawodawstwo konkurencyjne — art. 72 i 74 UZ oraz zakres wyłącznego ustawodawstwa krajów związkowych — art. 73 UZ. Zob. m.in. I. von Münch, op. cit., s. 56.

${ }^{10}$ Bundesverfassungsgericht - zob. art. 93 UZ oraz przepisy ustawy o FTK - Bundesverfassungsgerichtsgesetz, https://www.gesetze-im-internet.de/bverfgg/BJNR002430951.html (dostęp: 8.02.2020).

$11 \S \S 75-107$ Geschäftsordnung des Deutschen Bundestages in der Fassung der Bekanntmachung vom 2. Juli 1980 (BGB1 I S. 1237), ostatnia zmiana — Bekanntmachung vom 1. März 2019 (BGB1 I S. 197), https://www.bundestag.de/parlament/aufgaben/rechtsgrundlagen/go_btg (dostęp: 7.02.2020).

$12 \S 31$ Geschäftsordnung des Bundesrates in der Fassung der Bekanntmachung vom 26. November 1993 (BGB1 I S. 2007), ostatnio zmieniony w 2007 roku — Beschluss des Bundesrates vom 8. Juni 2007 (BGB1 I S. 1057), https://www.bundesrat.de/DE/aufgaben/recht/go/go-node.html (dostęp: 7.02.2020).

${ }^{13} \S 14$ Geschäftsordnung für den Gemeinsamen Ausschuss vom 23. Juli 1969 (BGBl I S. 1102), ostatnia zmiana - Bekanntmachung vom 20. Juli 1993 (BGBl I S. 1500), https://www.bundesrat.de/ DE/aufgaben/gemeins-a/geschaeftsordnung/gemeinsamer-ausschuss-geschaeftsordnung-node.html (dostęp: 7.02.2020).

Przegląd Prawa i Administracji CXX, 2020, cz. 1 i 2

(C) for this edition by CNS 
ne obciążenie dla budżetu federalnego wymagana jest dodatkowo zgoda rządu federalnego. Wymóg ten wynika bezpośrednio z art. $113 \mathrm{UZ}$.

\section{A. INICJATYWA USTAWODAWCZA}

Bundestag uchwala wszystkie ustawy należące według przepisów Ustawy Zasadniczej do kompetencji władz federalnych. Projekty ustaw do Bundestagu mogą wnosić, zgodnie z art. $76 \mathrm{UZ}$, rząd federalny, Bundestag oraz Bundesrat. W przypadku projektów Bundestagu prawo ich wniesienia przysługuje frakcji Bundestagu lub grupie posłów, jeżeli taki projekt poselski uzyska poparcie przynajmniej 5\% wszystkich posłów do Bundestagu.

\section{B. PRZEBIEG PROCEDURY USTAWODAWCZEJ}

Ustawy uchwalane są w trzech czytaniach na sesjach planarnych Bundestagu. Po pierwszym czytaniu trafiają do rozpatrzenia w jednej lub kilku komisjach stałych, w których uczestniczą posłowie wszystkich frakcji. Na posiedzenia komisji mogą być zapraszani przedstawiciele grup interesu i eksperci, którzy uczestniczą w wysłuchaniach publicznych (öffentliche Anhörung) ${ }^{14}$. W trakcie drugiego czytania na posiedzeniu plenarnym Bundestagu możliwe jest zgłaszanie poprawek. Trzecie czytanie, podczas którego ewentualne poprawki mogą wnioskować jedynie frakcje lub grupa posłów stanowiąca co najmniej 5\% ogółu posłów, kończy się głosowaniem. Do przyjęcia ustawy wymagana jest większość oddanych głosów, chyba że przepisy Ustawy Zasadniczej wymagają uzyskania innej kwalifikowanej większości. Uchwalona ustawa przekazywana jest do Bundesratu, który uchwałę w sprawie przyjęcia ustawy podejmuje zwykłą większością lub większością dwóch trzecich głosów. Taka sama większość jest konieczna do odrzucenia sprzeciwu Bundesratu w Bundestagu.

\section{PROCEDURA MEDIACYJNA}

Jeżeli Bundesrat i Bundestag nie są zgodne co do przyjęcia przekazanej do Bundesratu ustawy, kompromis wypracowuje Komisja Mediacyjna (Vermittlungsausschuss), składająca się z 16 członków Bundestagu i 16 członków Bundesratu. Bundesrat ma prawo zwrócenia się do Komisji Mediacyjnej w każdym przypadku, a Bundestag i rząd federalny jedynie w wypadku ustaw wymagających zgody Bundesratu. Zmiany zaproponowane przez Komisję Mediacyjną wymagają najpierw przyjęcia przez Bundestag, a następnie przez Bundesrat.

\section{WEJŚCIE USTAWY FEDERALNEJ W ŻYCIE}

Zgodnie z art. 82 UZ Prezydent Federalny po sprawdzeniu, czy ustawa została uchwalona w sposób zgodny z Ustawą Zasadniczą, podpisuje ją ${ }^{15}$ i zarządza

14 Wysłuchania publiczne zostały omówione w odrębnej części opracowania.

15 Podpisanie ustawy przez Prezydenta Federalnego określane jest jako Ausfertigung, co oznacza nie tylko sam akt złożenia podpisu przez głowę państwa, ale sprawdzenie, czy ustawa została 
ogłoszenie w Federalnym Dzienniku Ustaw. Ustawa z zasady wchodzi w życie 14 dni po jej opublikowaniu ${ }^{16}$.

\section{E. WYSŁUCHANIA PUBLICZNE}

Regulamin Bundestagu przewiduje możliwość udziału obywateli w publicznych wysłuchaniach ${ }^{17}$. Wysłuchania takie mogą być zarządzone przez komisję rozpatrującą projekt ustawy, jeżeli dotyczy on wyjątkowo skomplikowanej materii. Ich celem jest uzyskanie opinii specjalistów w danej dziedzinie lub grupy interesów, której ustawa ma dotyczyć, a także obywateli. Jednak ani biegli, ani inni uczestnicy wysłuchania nie mogą wpłynąć bezpośrednio na zmiany projektu ustawy.

W zakresie stanowienia prawa federalnego obowiązuje zasada demokracji przedstawicielskiej, gwarantująca tym samym monopol Bundestagu na uchwalanie ustaw. Przy zasadzie wolnego mandatu posłów wpływ obywateli na przedmiot procesu ustawodawczego wydaje się jeszcze bardziej ograniczony.

\section{USTAWODAWSTWO LANDÓW}

Z obowiązującej w Niemczech zasady federalizmu wynika między innymi podział kompetencji ustawodawczych pomiędzy Federację a landy ${ }^{18}$. Reforma federalizmu ${ }^{19}$ przeprowadzona w latach 2006 i 2009 wprowadziła nową strukturę podziału kompetencji ustawodawczych.

Zasady procedury ustawodawczej $\mathrm{w}$ landach wynikają $\mathrm{z}$ przepisów Ustawy Zasadniczej oraz przepisów krajowych. Każdy z 16 niemieckich landów ma

przyjęta zgodnie z obowiązującymi przepisami; zob. http://www.bundespraesident.de/DE/Amtund-Aufgaben/Wirken-im-Inland/Amtliche-Funktionen/amtliche-funktionen-node.html (dostęp: 12.02.2020).

${ }^{16}$ Zob. m.in. https://www.bundestag.de/pl/parlament/aufgaben-inhalt-638170 (dostęp: 7.02.2020).

$17 \S 70$ Geschäftsordnung des Bundestages.

18 Zasady tego podziału uregulowane są w Ustawie Zasadniczej; zob. przyp. 23.

${ }^{19}$ Gesetz zur Änderung des Grundgesetzes (BGBl 2006, I S. 2034), art. 22, 23, 33, 52, 72, $73,74,74 \mathrm{a}, 75,84,85,87 \mathrm{c}, 91 \mathrm{a}, 91 \mathrm{~b}, 93,98,104 \mathrm{a}, 104 \mathrm{~b}, 105,107,109,125 \mathrm{a}, 125 \mathrm{~b}, 125 \mathrm{c}, 143 \mathrm{c}$, https://dejure.org/BGBl/2006/BGB1._I_S._2034 (dostęp: 10.02.2020). Była to 52. zmiana Ustawy Zasadniczej, wprowadzająca największe zmiany w organizacji państwa od czasów utworzenia Republiki Federalnej Niemiec w 1949 roku. Zmiany te zostały uzupełnione w ramach drugiego etapu reformy federalizmu na drodze ustawy z 29 lipca 2009 roku — Gesetz zur Änderung des Grundgesetzes (BGB1 2009, I S. 2284), art. 91c, 91d, 104b, 109, 109a, 115, 143d, https://www.bgbl.de/xaver/ bgbl/start.xav?startbk=Bundesanzeiger_BGB1\&bk=Bundesanzeiger_BGB1\&start=//*05B@attr_ id=\%27bgbl109s2248.pdf\%27\%5D\#_bgbl_\%2F\%2F*\%5B\%40attr_id\%3D\%27bgbl109s2248. pdf\%27\%5D_1581701507738 (dostęp: 10.02.2020); zob. S. Bożyk, Kierunki nowelizacji Ustawy Zasadniczej RFN (zarys problematyki), [w:] Aktualne problemy reform konstytucyjnych, red. S. Bożyk, Białystok 2013, s. 367 n. 
swoją konstytucję ${ }^{20}$ oraz strukturę organizacyjną odpowiadającą strukturze państwowej. W landach istnieją zatem parlament (Landtag), rząd (Landesregierung) i sąd konstytucyjny (Verfassungsgericht). Zasady powoływania i funkcjonowania tych organów oraz ich kompetencje uregulowane są w konstytucjach oraz odpowiednich ustawach tych landów (Landesgesetz). Landy w zakresie stanowienia swoich konstytucji i ustawodawstwa zobowiązane są jedynie do przestrzegania przepisów Ustawy Zasadniczej, mianowicie art. 28 ust. 1 zd. 1, zgodnie z którym porządek konstytucyjny krajów związkowych musi odpowiadać zasadom republikańskiego, demokratycznego i socjalnego państwa prawnego w rozumieniu Ustawy Zasadniczej, oraz art. 79 ust. 3, który gwarantuje zasadę niezmienności zasad konstytucyjnych dla Federacji i landów — także zasady zawartej w art. 20 UZ. Przy zachowaniu tych zasad przepisy konstytucji landów mogą odbiegać od postanowień Ustawy Zasadniczej, na przykład mogą wprowadzać stosowanie instrumentów demokracji bezpośredniej, których wykonywanie nie jest możliwe na poziomie federacji.

\section{A. INSTRUMENTY DEMOKRACJI BEZPOŚREDNIEJ W POSTĘPOWANIU USTAWODAWCZYM W LANDACH}

W konstytucjach poszczególnych landów występuje różny zakres stosowania instrumentów demokracji bezpośredniej. W dodatku ustawodawcy landów dla tych samych instytucji używają czasem różnych pojęć. Najbardziej ogólnym pojęciem jest Volksgesetzgebung, które należy rozumieć jako procedurę ustawodawczą z udziałem obywateli. Ponadto w konstytucjach landów występują pojęcia: Volksinitiative ${ }^{21}$, tłumaczone na język polski jako „,inicjatywa ludowa” lub ,inicjatywa narodu/obywatelska”, oraz Volksbegehren ${ }^{22}$ — w znaczeniu ,społecznej/ obywatelskiej inicjatywy ustawodawczej”, a w dosłownym thumaczeniu ,żądanie narodu"23. Pojęcie to oznacza wniosek uprawnionych obywateli o przeprowadze-

${ }^{20}$ Konstytucje landów były uchwalane w różnym czasie, zarówno przed, jak i po uchwaleniu Ustawy Zasadniczej, na przykład Konstytucja Bawarii w 1946 roku, a konstytucje tak zwanych nowych landów — po zjednoczeniu Niemiec 3 października 1990 roku. Teksty wszystkich konstytucji dostępne są w dziennikach ustaw poszczególnych landów.

${ }^{21}$ W Brandenburgii, Hamburgu, Meklemburgii-Pomorzu Przednim, Dolnej Saksonii, Północnej Nadrenii-Westfalii, Saksonii-Anhalt, Szlezwiku-Holsztynie; zob. B.M. Weixner, Direkte Demokratie in den Bundesländern, „Aus Politik und Zeitgeschichte” 10, 2006, s. 19.

${ }^{22} \mathrm{~W}$ wypadku instytucji Volksbegehren konieczne jest złożenie projektu ustawy — uzasadnia to używanie w języku polskim tłumaczenia tego pojęcia jako „obywatelska” lub „społeczna inicjatywa ustawodawcza"; zob. I. Kienzler, Wörterbuch der Wirtschaftssprache, Deutsch-Polnisch, Polnisch-Deutsch. Bankwesen, Finanzen, Recht, Warszawa 2004, s. 311: „Volksbegehren - oddanie sprawy narodowi do rozstrzygnięcia, referendum".

${ }^{23}$ Niektórzy autorzy traktująje na równi z pojęciem referendum; zob. P. Neumann, Sachunmittelbare Demokratie im Bundes- und Landesverfassungsrecht unter besonderer Berücksichtigung der neuen Länder, Baden Baden 2009, s. 181, 182. Więcej na temat pojęć stosowanych do określenia instrumentów demokracji bezpośredniej w Niemczech i ich tłumaczenia na język polski zob. A. Malicka, Referendum 
nie referendum w pewnej sprawie, zwykle przyjęcia konkretnej ustawy ${ }^{24}$. Obywatele występujący z takim żądaniem są zobowiązani do złożenia swojego projektu ustawy do organu ustawodawczego ${ }^{25}$.

Jako forma podejmowania decyzji w sprawie obywatelskiej inicjatywy ustawodawczej w konstytucjach landów wymieniane jest także pojęcie Volksentscheid, które należy rozumieć jako referendum; w dosłownym tłumaczeniu — „decyzja narodu". W południowozachodnim obszarze niemieckojęzycznym ${ }^{26} \mathrm{~W}$ znaczeniu referendum używane jest jeszcze pojęcie Volksabstimmung, które dosłownie tłumaczone oznaczałoby ,głosowanie ludowe” lub „głosowanie narodu”. Wskazane instrumenty demokracji bezpośredniej znajdują zastosowanie w procedurze ustawodawczej w landach.

\section{B. PROCEDURA USTAWODAWCZA Z INICJATYWY OBYWATELI W LANDACH}

Sposób uchwalania ustaw na poziomie landów uregulowany jest w konstytucji każdego z nich ${ }^{27}$. Zasadniczo procedury te przebiegają w zbliżony sposób. Podobnie jak na poziomie Federacji także w landach dominuje zasada demokracji przedstawicielskiej, co oznacza, że stanowienie prawa należy do kompetencji pochodzących z wyborów Landtagów. W wypadku landów konstytucje wszystkich 16 od 1996 roku $^{28}$ przewidują jednak także możliwość przyjęcia ustawy na drodze referendum.

Można tu przykładowo wskazać na postanowienia Konstytucji Bawarii. Zgodnie $\mathrm{z}$ art. 72 ust. 1 ustawy krajowe uchwalane są przez Landtag i na drodze referendum ${ }^{29}$. Szczegóły takiej procedury ustawodawczej uregulowane są w art. 74 Konstytucji Bawarii oraz w odrębnej ustawie, mianowicie w bawarskiej ustawie wyborczej ${ }^{30}$. Podobne postanowienia zwiera także rozdział IV Konstytucji Badenii-

w systemie prawa niemieckiego, [w:] B. Tokaj, A. Feja-Paszkiewicz, B. Banaszak, Aktualne problemy referendum, Warszawa 2016, s. 255-271.

${ }^{24}$ Zob. H.J. Wiegand, Direktdemokratische Elemente in der Deutschen Verfassungsgeschichte, Juristische Zeitgeschichte, Abt. 1, Allgemeine Reihe, t. 20, Berlin 2006, s. 27 n.

${ }^{25} \mathrm{~W}$ przypadku landów - do parlamentu krajowego, czyli Landtagu.

${ }^{26} \mathrm{Na}$ przykład w Badenii-Wirtembergii oraz w Szwajcarii i Lichtensteinie.

27 W niniejszym opracowaniu nie zostały szczegółowo omówione postępowania ustawodawcze we wszystkich 16 landach, a jedynie ogólne zasady, według których uchwalane są ustawy.

${ }^{28}$ Ostatnim landem, w którym wprowadzono taką możliwość, był Hamburg; zob. F. Hoffmann, Volksgesetzgebung und politischer Entscheidungsprozess, „Würzburger Arbeitspapiere zur Politikwissenschaft und Soziologie" 2018, nr 9, s. 10.

${ }^{29}$ Art. 72 ust. 1 Konstytucji Bawarii; ustawodawca posługuje się w tym wypadku pojęciem Volksentscheid do określenia referendum.

${ }^{30}$ Gesetz über Landtagswahl, Volksbegehren und Volksentscheid (BayGVB1 S. 367); w części III ustawy (art. 62-88) uregulowane zostały: społeczna inicjatywa ustawodawcza (Volksbegehren), referendum (Volksentscheid), możliwość odwołania Landtagu oraz możliwość potwierdzenia lub odrzucenia dokonanej przez Landtag zmiany konstytucji na drodze referendum oraz wskazane wyłączenia wynikające z art. 73 Konstytucji Bawarii. 
-Wirtembergii ${ }^{31}$. Zgodnie z art. 59 projekty ustaw mogą być wnoszone także przez obywateli32, a ustawy uchwalane są przez Landtag lub na drodze referendum.

Jako land z dobrze funkcjonującą instytucją inicjatywy ustawodawczej obywateli wymieniana jest także Nadrenia-Palatynat. W art. 108a jej konstytucji przewidziano inicjatywę obywateli ${ }^{33}$ kierowaną do Landtagu w celu zajęcia się przezeń konkretną sprawą, a w art. 109 — instytucję obywatelskiej inicjatywy ustawodawczej i przyjęcia ustawy na drodze referendum.

Zasadniczo procedura ustawodawcza $\mathrm{z}$ inicjatywy obywateli ${ }^{34}$ jest trójstopniowa. W zależności od landu rozpoczyna się od inicjatywy obywatelskiej (Volksinitiative) lub wniosku o obywatelską inicjatywę ustawodawczą. Następnym etapem jest obywatelska inicjatywa ustawodawcza (Volksbegehren), polegająca na przedłożeniu Landtagowi projektu konkretnej ustawy. Obywatele muszą zebrać w określonym ustawowo terminie podpisy popierające inicjatywę obywatelską. Liczba wymaganych podpisów jest zależna od landu i określana procentowo lub za pomocą konkretnej liczby ${ }^{35}$. Podpisy muszą zostać zebrane również pod wnoszonym projektem ustawy. Procedura ustawodawcza kończy się przyjęciem ustawy na drodze referendum (Volksantscheid lub Volksabstimmung). Uprawnionymi do udziału w stanowieniu prawa są obywatele, którym przysługuje czynne prawo wyborcze do Landtagu. Aby wynik głosowania był wiążący, wymagane jest uzyskanie kworum ${ }^{36}$.

Według danych przedstawionych między innymi w sprawozdaniu stowarzyszenia Mehr Demokratie ${ }^{37}$ z roku na rok wzrasta zaangażowanie obywateli i ich świadomość, że rzeczywiście mają możliwość wpływania na podejmowane przez lokalne parlamenty decyzje i stanowione przez nie prawo. Liczba inicjowanych przez obywateli procedur ustawodawczych zwiększa się każdego roku, chociaż

31 Verfassung des Landes Baden-Württemberg vom 11. November 1953 (GBl. BW S. 173), https://www.lpb-bw.de/bwverf/bwverf.htm (dostęp: 12.02.2020). Inicjatywa ustawodawcza obywateli przewidziana jest w Konstytucji od chwili jej uchwalenia w 1952 roku, w 2015 roku zaś przepisy zostały zmienione, aby ułatwić obywatelom bezpośredni udział w stanowieniu prawa; zob. https:// www.lpb-bw.de/volksabstimmung-in-bw/ (dostęp: 12.02.2020).

${ }^{32}$ Ustawa przewiduje wniosek obywateli (Volksantrag) lub obywatelską inicjatywę ustawodawczą (Volksbegehren).

${ }^{33}$ Ustawodawca używa pojęcia Volksinitiative, w odróżnieniu od uregulowanej w art. 109 inicjatywy ustawodawczej (Volksbegehren).

${ }^{34} \mathrm{~W}$ niektórych landach istnieje także możliwość zarządzenia referendum w sprawie uchwalenia ustawy przez rząd krajowy lub Landtag. Określane są one wówczas jako Parlamentsreferendum, czyli referendum parlamentarne. Te przypadki nie zostały jednak uwzględnione w niniejszym opracowaniu.

${ }^{35}$ Minimalna liczba wymaganych podpisów wynosi około 4-13\%. Szczegółowe informacje o wymaganej liczbie podpisów zob. Volksbegehrensbericht 2019, s. 12, https://www.mehr-demokratie.de/volksbegehrensbericht/ (dostęp: 12.02.2020).

${ }^{36}$ Kworum wynosi 15-25\%, a w Bawarii i Saksonii kworum nie jest wymagane. W wypadku referendum dotyczącego zmiany konstytucji kworum jest wyższe i wynosi 50\%, a w Turyngii i Bremie - 40\%; zob. ibidem.

37 Ibidem. 
tylko nieliczne inicjatywy kończą się sukcesem ${ }^{38}$. Od 1946 do 2018 roku we wszystkich landach wszczęto łącznie 351 takich procedur ${ }^{39}$, z czego 95 zostało doprowadzonych do drugiego etapu postępowania — złożenia projektu ustawy. Ostatecznie zaledwie 24 inicjatywy obywatelskie zostały doprowadzone do ostatniego etapu postępowania, czyli referendum ${ }^{40}$.

\section{POSTULAT ZMIAN USTAWY ZASADNICZEJ - WIĘCEJ DEMOKRACJI BEZPOŚREDNIEJ}

Od wielu lat ${ }^{41} \mathrm{w}$ Niemczech dyskutuje się o potrzebie zwiększenia udziału obywateli w życiu politycznym, w tym o umożliwieniu im bezpośredniego wpływania na podejmowane przez Parlament Federalny decyzje przez wprowadzenie instytucji obywatelskiej inicjatywy ustawodawczej oraz referendum ogólnokrajowego $^{42}$. Kilkukrotnie w Bundestagu złożone zostały także projekty ustaw ${ }^{43}$, których celem było wprowadzenie ustawodawczej inicjatywy obywatelskiej do Ustawy Zasadniczej. Ostatnio takie projekty zostały złożone przez partie Die Linke oraz $\mathrm{AfD}^{44}$. Projekt AfD nie został jeszcze poddany głosowaniu, a zawiera następujące propozycje zmian: wprowadzenie obywatelskiej inicjatywy ustawodawczej ${ }^{45}$ oraz

${ }^{38}$ Dokładne zestawienie przeprowadzonych do 2019 roku w landach procedur z inicjatywy obywateli zob. ibidem, s. 15 .

${ }^{39}$ Inicjatywa obywatelska najczęściej stosowana jest w Bawarii (57), Hamburgu (50) i Brandenburgii (49); zob. https://www.mehr-demokratie.de/volksbegehrensbericht/ (dostęp: 12.02.2020).

40 Do początku lat dziewięćdziesiątych było ich zaledwie 28, a liczba ta wzrosła znacznie od 1990 roku, kiedy większość landów zapoczątkowała reformę przepisów konstytucyjnych dotyczących demokracji bezpośredniej; zob. ibidem.

${ }^{41}$ Pierwsze konkretne projekty zmiany Ustawy Zasadniczej wpłynęły do Bundestagu w 2002 roku.

${ }^{42} \mathrm{~W}$ tym celu partia AfD złożyła 18 kwietnia 2018 roku w Bundestagu wniosek o powołanie komisji ankietowej, która miałaby opracować odpowiedni projekt ustawy zmieniającej Ustawę Zasadniczą; zob. Antrag: Einsetzung einer Enquete-Kommission „Direkte Demokratie auf Bundesebene" (Drucksache 19/1699). Wniosek został odrzucony przez Bundestag w głosowaniu przeprowadzonym 4 kwietnia 2019 roku; https://www.bundestag.de/dokumente/textarchiv/2019/ kw14-de-direkte-demokratie-630910 (dostęp: 12.02.2020).

${ }^{43} \mathrm{~W}$ 14. kadencji Bundestagu wpłynęły dwa takie projekty: Drucksachen 14/1129 oraz 14/8503. W 15. kadencji - Drucksachen 15/1112 oraz 15/2998, a w 16. kadencji — trzy projekty opracowane przez: Die Linke - Drucksache 16/1411, Bündnis90/Die Grünen - Drucksache 16/680 oraz FDP — Drucksache 16/47; w 18. kadencji — kolejny projekt Die Linke — Drucksache $18 / 825$.

${ }^{44}$ Zob. przyp. 6. Projekt Die Linke został odrzucony, nad projektem AfD do chwili oddania tego opracowania do druku nie odbyło się jeszcze głosowanie w Bundestagu. Biorąc jednak pod uwagę brak poparcia innych frakcji Bundestagu dla działań podejmowanych przez AfD, losy tego projektu wydają się przesądzone.

${ }^{45}$ Zmiana art. 76 ust. $1 \mathrm{UZ}$. 
referendum ogólnokrajowego jako jednej z form uchwalania ustaw federalnych ${ }^{46}$, w tym możliwość zmiany Ustawy Zasadniczej ${ }^{47}$. Ponadto projekt zawiera propozycję zmian w zakresie aktywnego prawa wyborczego do Bundestagu ${ }^{48}$. Prawo wyborcze miałoby przysługiwać obywatelom niemieckim, którzy ukończyli 16. rok życia, a także osobom niemającym niemieckiego obywatelstwa, jeżeli ukończyły 16. rok życia i od co najmniej pięciu lat posiadają na terytorium Niemiec mieszkania lub stałe miejsce pobytu. AfD proponuje też dodanie do Ustawy Zasadniczej rozdziału VIIa ${ }^{49}$, zawierającego przepisy regulujące stosowanie inicjatywy obywatelskiej, obywatelskiej inicjatywy ustawodawczej oraz referendum.

Prawo wniesienia inicjatywy obywatelskiej miałoby przysługiwać grupie 100 tysięcy osób mających prawo wyborcze. Wyklucza się jednocześnie inicjatywę dotyczącą podziału Federacji na landy, udziału landów w procedurze ustawodawczej, zmian praw podstawowych zawartych w art. 1-20 UZ oraz budżetu federalnego, a ewentualne zmiany Ustawy Zasadniczej nie mogłyby naruszać istoty praw podstawowych. Obywatelska inicjatywa ustawodawcza mogłaby zostać wniesiona najwcześniej po upływie dwóch miesięcy po odrzuceniu inicjatywy obywatelskiej przez Bundestag i stałaby się skuteczna pod warunkiem zebrania w ciągu dziewięciu miesięcy 1 miliona podpisów osób uprawnionych do udziału w wyborach, natomiast $\mathrm{w}$ wypadku zmiany Ustawy Zasadniczej wymagane miałoby być zebranie 2 milionów podpisów. W przypadku braku zgody rządu federalnego, rządu krajowego lub jednej trzeciej członków Bundestagu na wniesioną inicjatywę ustawodawczą obywateli decyzję o jej losach miałby podejmować Federalny Trybunał Konstytucyjny w terminie sześciu miesięcy. Jeżeli Bundestag w ciągu trzech miesięcy nie odpowie na wniosek obywateli, wówczas nie wcześniej niż przed upływem czterech miesięcy i nie później niż dwunastu miesięcy po wniesieniu inicjatywy ustawodawczej do Bundestagu miałoby się odbyć referendum. Bundestag może przedłożyć pod głosowanie także własny projekt ustawy w tym samym zakresie.

Wynik referendum miałby być wiążący, jeżeli projekt ustawy uzyska większość oddanych głosów, a w głosowaniu uczestniczyło co najmniej 15\% uprawnionych do udziału w wyborach osób. Pod uwagę byłyby brane tylko ważne głosy „za” i „przeciw”. W wypadku równości głosów ustawa zostałaby odrzucona. W przypadku zmiany Ustawy Zasadniczej wymagana miałaby być większość dwóch trzecich głosów przy udziale w głosowaniu co najmniej 25\% uprawnionych. Szczegółowe regulacje miałaby zawierać odpowiednia ustawa federalna przyjęta za zgodą Bundesratu.

\footnotetext{
46 Zmiana art. $77 \mathrm{UZ}$.

47 Zmiana art. 79 ust. 2 UZ.

48 Zmiana art. $38 \mathrm{UZ}$.

49 Rozdział ten miałby znaleźć się po art. 82 UZ.
} 


\section{STANOWISKA PARTII REPREZENTOWANYCH W BUNDESTAGU DOTYCZAॄCE WPROWADZENIA DEMOKRACJI BEZPOŚREDNIEJ DO USTAWY ZASADNICZEJ}

Obecnie spośród partii reprezentowanych w Bundestagu 19. kadencji tylko jedna partia - $\mathrm{CDU}^{50}$ - nie popiera wprowadzenia odpowiednich przepisów do Ustawy Zasadniczej. Pozostałe partie w swoich programach w różnym stopniu opowiadają się za wzmocnieniem demokracji bezpośredniej.

\section{UNIA CHRZEŚCIJAŃSKO-DEMOKRATYCZNA NIEMIEC - CHRISTLICH DEMOKRATISCHE UNION (CDU)}

Z programu partii ${ }^{51}$ wynika, że CDU wyraźnie opowiada się za demokracją reprezentacyjną jako formą sprawowania władzy przez suwerena i utrzymaniem takiego rozwiązania także w przyszłości.

\section{UNIA CHRZEŚCIJAŃSKO-SPOŁECZNA - CHRISTLICH SOZIALE UNION (CSU)}

$\mathrm{CSU}^{52}$, podkreślając swoją wieloletnią tradycję demokracji parlamentarnej, wymienia jako jeden z programowych celów wprowadzenie możliwości bezpośredniego udziału obywateli w decyzjach o ważnych dla całej Federacji sprawach, a także zmiany niemieckiej Ustawy Zasadniczej przez obywateli na drodze znanej $\mathrm{z}$ landów obywatelskiej inicjatywy ustawodawczej i referendum ${ }^{53}$. Postulat ten znalazł się również w programie wyborczym CSU z 2017 roku $^{54}$.

\section{SOCJALDEMOKRATYCZNA PARTIA NIEMIEC - SOZIALDEMOKRATISCHE PARTEI DEUTSCHLANDS (SPD)}

SPD $^{55}$ swoje poparcie dla demokracji bezpośredniej wyraziła zarówno w swoim zasadniczym programie ${ }^{56}$, jak i w programie wyborczym z 2017 roku $^{57}$. Wprowa-

50 Partia rządząca po wyborach w 2017 roku, w koalicji z CSU i SPD.

${ }^{51}$ Zob. Das Grundsatzprogramm. Beschlossen vom 21. Parteitag Hannover, 3-4. Dezember 2007, s. 88, pkt 283, https://www.cdu.de/grundsatzprogramm (dostęp: 5.02.2020). Aktualnie obowiązującym programem CDU jest przyjęty w 2007 roku tak zwany trzeci program zasadniczy.

52 Partia istniejąca jedynie w Bawarii, tworzy unię CDU/CSU.

${ }^{53}$ Die Ordnung. Das Grundsatzprogramm der Christlich-Sozialen Union, s. 86-87, http://csugrundsatzprogramm.de/grundsatzprogramm-gesamt/ (dostęp: 5.02.2020).

${ }^{54}$ Wahlprogramm 2017 Bayernplan, pkt Beteiligungsgarantie, s. 2, https://www.csu.de/politik/beschluesse/bayernplan-2017/ (dostęp: 5.02.2020).

55 Jest to najstarsza działająca w Niemczech (od ponad 150 lat) partia polityczna.

${ }^{56}$ Hamburger Programm Grundsatzprogramm der Sozialdemokratischen Partei Deutschlands Beschlossen auf dem Hamburger Bundesparteitag der SPD am 28. Oktober 2007, s. 32-33, https:// www.spd.de/partei/organisation/das-grundsatzprogramm/ (dostęp: 5.02.2020).

${ }^{57}$ Zeit für mehr Gerechtigkeit. Unser Regierungsprogramm für Deutschland, s. 79, https://www. bundestagswahl-bw.de/wahlprogramm-spd-btwahl2017 (dostęp: 5.02.2020). 
dzenie instytucji obywatelskiej inicjatywy ustawodawczej i referendum na poziomie federalnym ma jej zdaniem służyć przede wszystkim uzupełnieniu demokracji parlamentarnej oraz wzmocnieniu aktywnego społeczeństwa obywatelskiego.

\section{ALTERNATYWA DLA NIEMIEC — ALTERNATIVE FÜR DEUTSCHLAND (AFD)}

$\mathrm{AfD}^{58} \mathrm{w}$ swoim zasadniczym programie odwołuje się bezpośrednio do szwajcarskiego wzorca demokracji bezpośredniej ${ }^{59}$. Jednym z celów programowych jest wprowadzenie do Ustawy Zasadniczej możliwości głosowania obywateli nad uchwalonymi przez Bundestag ustawami oraz prawa obywatelskiej inicjatywy ustawodawczej, także inicjatywy zmiany konstytucji. Program AfD wyklucza możliwość zmiany Ustawy Zasadniczej lub zawarcia jakiejkolwiek istotnej umowy międzynarodowej bez zgody narodu. Te postulaty zostały wyraźnie zaznaczone w programie wyborczym z 2017 roku $^{60}$. Demokracja bezpośrednia ma być sposobem kontroli ustawodawcy przez obywateli ${ }^{61}$.

\section{WOLNA PARTIA DEMOKRATYCZNA — FREIE DEMOKRATISCHE PARTEI (FDP)}

Zasadniczy program $\mathrm{FDP}^{62}$ zawiera postulat wprowadzenia obywatelskiej inicjatywy ustawodawczej i referendum na poziomie federalnym. W programie wyborczym z 2017 roku $^{63}$ partia dodatkowo podkreśliła konieczność wzmocnienia demokracji liberalnej przez zwiększenie zaangażowania obywateli w życie polityczne i rozbudowywanie instrumentów demokracji bezpośredniej także na poziomie komunalnym i krajowym.

\section{LEWICA - DIE LINKE}

Lewica postuluje w swoim programie ${ }^{64}$ konieczność odnowienia Niemiec jako państwa prawa i państwa socjalnego poprzez uzupełnienie parlamentarnej

58 Partia eurosceptyczna i zdecydowanie sprzeciwiająca się przyjmowaniu migrantów do Niemiec, powstała przed wyborami parlamentarnymi w 2013 roku.

${ }^{59}$ Grundsatzprogramm, s. 2, https://www.afd.de/demokratie-in-deutschland/(dostęp: 5.02.2020).

${ }^{60}$ Programm für Deutschland. Wahlprogramm der Alternative für Deutschland für die Wahl zum Deutschen Bundestag am 24. September 2017, s. 8-9, www.afd.de/wahlprogramm (dostęp: 5.02.2020).

${ }^{61}$ Frakcja AfD w Bundestagu wniosła 13 sierpnia 2019 roku projekt zmiany Ustawy Zasadniczej (Drucksache 19/12371).

${ }^{62}$ Grundsatzprogramm: Verantwortung für die Freiheit. Karlsruher Freiheitsthesen der FDP für eine offene Bürgergesellschaft. Beschluss des 63. Ordentlichen Bundesparteitages der FDP Karlsruhe, 22. April 2012, s. 73, https://www.fdp.de/content/leitbild-grundsatzprogramm (dostęp: 5.02.2020).

${ }^{63}$ Denken wir neu. Das Programm der Freien Demokraten zur Bundestagswahl 2017 „Schauen wir nicht länger zu", s. 96, https://www.fdp.de/content/bundestagswahlprogramm-2017 (dostęp: 5.02.2020).

${ }^{64}$ Programm der Partei Die Linke. Beschluss des Parteitages der Partei Die Linke vom 21. bis 23. Oktober 2011 in Erfurt, bestätigt durch einen Mitgliederentscheid im Dezember 2011, s. 45, https:/www.die-linke.de/partei/grundsatzdokumente/programm/ (dostęp: 5.02.2020). 
demokracji reprezentacyjnej o elementy demokracji bezpośredniej. W programie wyborczym ${ }^{65}$ podkreśla konieczność zapewnienia obywatelom bezpośredniego wpływu na decyzje polityczne, w szczególności przez organizację ogólnokrajowych referendów ${ }^{66}$.

\section{SOJUSZ 90/ZIELONI — BÜNDNIS 90/DIE GRÜNEN}

Także Sojusz 90/Zieloni67 ${ }^{6}$ popiera w swoim programie zasadniczym ${ }^{68}$ postulat uzupełnienia demokracji parlamentarnej poprzez rozbudowanie stosowania instrumentów demokracji bezpośredniej od poziomu komunalnego po poziom federalny. W programie wyborczym z 2017 roku $^{69}$ partia postuluje wprowadzenie do Ustawy Zasadniczej obywatelskiej inicjatywy ustawodawczej i referendum rozwiązań znanych z landów.

\section{PODSUMOWANIE}

Przy analizie praktyki landów w zakresie stosowania instrumentów demokracji bezpośredniej nasuwa się wniosek, że obywatele bardzo cenią sobie możliwość bezpośredniego wpływania na stanowienie prawa, nawet jeśli większość inicjatyw kończy się niepowodzeniem,

Aktualny skład Bundestagu i fakt, że projekt zmian został wniesiony przez kontrowersyjną frakcję AfD, nie daje jednak nadziei na szybkie wprowadzenie zmian gwarantujących stosowanie demokracji bezpośredniej na poziomie federalnym. Biorąc jednak pod uwagę aktywny udział obywateli w życiu politycznym ${ }^{70}$ poprzez wybory czy korzystanie z prawa wnoszenia petycji oraz intensywny rozwój świadomego swoich praw społeczeństwa obywatelskiego, taka zmiana wydaje się nieunikniona, chociaż poważny kryzys demokracji bezpośredniej w wielu krajach świata będzie z pewnością stanowił dla Bundestagu sygnał ostrzegawczy przed wprowadzeniem tak ,rewolucyjnych zmian” w systemie prawa federalnego.

${ }^{65}$ Sozial. Gerecht. Frieden. Für alle. Die Zukunft, für die wir kämpfen, s. 108, https://archivwahlen.die-linke.de/bundestagswahl-2017/wahlprogramm/ (dostęp: 5.02.2020).

${ }^{66}$ Po wyborach w 2017 roku Lewica wniosła swój projekt ustawy zmieniającej Ustawę Zasadniczą.

${ }^{67}$ Partia powstała w 1993 roku z połączenia ruchów obywatelskich dawnego NRD z zachodnioniemiecką partią Zieloni.

${ }^{68}$ Die Zukunft ist grün. Grundsatzprogramm von Bündnis 90/Die Grünen. Beschlossen auf der Bundesdelegiertenkonferenz von Bündnis/Die Grünen am 15-17. März 2002 im Berliner Tempodrom, s. 129, https://www.gruene.de/grundsatzprogrammprozess (dostęp: 5.02.2020).

${ }^{69}$ Zukunft wird aus Mut gemacht. Bundestagswahlprogramm 2017, s. 148, https://www.gruene.de/beschluesse-und-programme (dostęp: 5.02.2020).

70 Według badań Fundacji Bertelsmanna 75\% obywateli opowiada się za demokracją bezpośrednią; zob. Partizipation im Wandel - unsere Demokratie zwischen Wählen, Mitmachen und Entscheiden, red. Bertelsmann Stiftung, Staatsministerium Baden, Gütersloh 2014, s. 2. 


\title{
PARTICIPATION OF CITIZENS IN THE LEGISLATIVE PROCEDURE IN THE FEDERAL REPUBLIC OF GERMANY
}

\author{
Summary
}

According to Article 20 of the Basic Law, the Federal Republic of Germany is a democratic, social, and federal state in which all power comes from the people and is exercised by them through elections and votes. In practice, voting, which is to be understood as an instrument of direct democracy, applies only to the new territorial division of the Länder. The instruments of direct democracy are more widely used in lawmaking in the individual Länder. Among other things, the law provides for citizens' legislative initiative. This would require an amendment to the Basic Law if federal law were to be passed. To date, proposals for such amendments have been rejected.

Keywords: legislative procedure, Bundestag, direct democracy, representative democracy, legislative initiative, referendum

\section{BIBLIOGRAFIA}

Bożyk S., Kierunki nowelizacji Ustawy Zasadniczej RFN (zarys problematyki), [w:] Aktualne problemy reform konstytucyjnych, red. S. Bożyk, Białystok 2013.

Grundgesetz. Mitarbeiterkommentar und Handbuch, t. 1, red. D. Umbach, T. Clemens, Heidelberg 2002.

Hoffmann F., Volksgesetzgebung und politischer Entscheidungsprozess, „Würzburger Arbeitspapiere zur Politikwissenschaft und Soziologie" 2018, nr 9.

Isensee J., Demokratie ohne Volksabstimmung, [w:] 60 Jahre Bonner Grundgesetz — eine geglückte Verfassung?, red. Ch. Hillgruber, Ch. Waldhoff, Bonn 2010.

Kienzler I., Wörterbuch der Wirtschaftssprache, Deutsch-Polnisch, Polnisch-Deutsch. Bankwesen, Finanzen, Recht, Warszawa 2004.

Lexikon Direkte Demokratie in Deutschland, red. A. Kost, M. Solar, Wiesbaden 2018.

Malicka, A., Referendum w systemie prawa niemieckiego, [w:] B. Tokaj, A. Feja-Paszkiewicz, B. Banaszak, Aktualne problemy referendum, Warszawa 2016.

Münch I., Staatsrecht, t. 1, wyd. 6, Stuttgart-Berlin-Köln 2000.

Neumann P., Sachunmittelbare Demokratie im Bundes- und Landesverfassungsrecht unter besonderer Berücksichtigung der neuen Länder, Baden Baden 2009.

Partizipation im Wandel - unsere Demokratie zwischen Wählen, Mitmachen und Entscheiden, red. Bertelsmann Stiftung, Staatsministerium Baden, Gütersloh 2014.

Weixner B.M., Direkte Demokratie in den Bundesländern, „Aus Politik und Zeitgeschichte” 10, 2006. Wiegand H.J., Direktdemokratische Elemente in der Deutschen Verfassungsgeschichte, Juristische Zeitgeschichte, Abt. 1, Allgemeine Reihe, t. 20, Berlin 2006. 